ISSN 0258-7122

Bangladesh J. Agril. Res. 34(1) : 81-90, March 2009

\title{
EFFECT OF INTEGRATED USE OF ORGANIC MANURES WITH CHEMICAL FERTILIZERS IN THE RICE-RICE CROPPING SYSTEM AND ITS IMPACT ON SOIL HEALTH
}

\author{
M.E. ALI ${ }^{1}$, M.R. ISLAM ${ }^{2}$ AND M. JAHIRUDDIN ${ }^{3}$
}

\begin{abstract}
A field experiment was conducted during 2003-2004 at Bangladesh Agricultural University farm, Mymensingh to evaluate the suitability of different sources of organic materials for integrated use with chemical fertilizers for the BoroFallow-T. Aman rice cropping pattern. The experiment was set up in a randomized complete block design (RCBD) with three replications. Eighttreatments, formulated from organic manure and chemical fertilizers have been imposed. The treatment combinations are $\mathrm{T}_{1}:$ control, $\mathrm{T}_{2}: 70 \% \mathrm{NPKS}, \mathrm{T}_{3}: 100 \%$ NPKS, $T_{4}: 70 \%$ NPKS + rice straw (RS) @ 5 t/ha, $\mathrm{T}_{5}: 70 \%$ NPKS + dhaincha (DH) @ 15 t/ha, T : 70\% NPKS + mungbean residue (MBR) @ 10 t/ha, $\mathrm{T}_{7}: 70 \%$ NPKS + cowdung (CD) @ 5 t/ha and $\mathrm{T}_{8}: 70 \%$ NPKS + poultry manure (PM) @ $3 \mathrm{t} / \mathrm{ha}$. Organic manure or crop residue was applied to T. Aman rice and their residual effects were observed in the following Boro rice. Application of $70 \%$ NPKS + PM produced the highest grain yield of T. Aman rice, which was identical to that obtained with $100 \%$ NPKS with no manure. In Boro season. application of 100\% NPKS produced the highest grain yield of $6.87 \mathrm{t} / \mathrm{ha}$, which was identical with the application of $70 \%$ NPKS + PM (6.57 t/ha). The total grain yield in the cropping pattern ranged from $5.14 \mathrm{t} / \mathrm{ha}$ in $\mathrm{T}_{1}$ (control) treatment to $12.29 \mathrm{t} / \mathrm{ha}$ in the $100 \%$ NPKS. The application of $3 \mathrm{t} / \mathrm{ha}$ PM with $70 \%$ NPKS $\left(\mathrm{T}_{8}\right)$ produced the total yield of $12.09 \mathrm{t} / \mathrm{ha}$ followed by $11.59 \mathrm{t} / \mathrm{ha}$ in the treatment containing $10 \mathrm{t} / \mathrm{ha}$ MBR plus $70 \%$ NPKS $\left(\mathrm{T}_{6}\right)$. It appears that the application of $3 \mathrm{t} /$ ha PM once in a year with $70 \%$ NPKS can reduce the use of $30 \%$ NPKS as fertilizers. There were negative balances for $\mathrm{N}$ and $\mathrm{K}$ with the highest mining of $\mathrm{K}$, while the balances for $\mathrm{P}$ and $\mathrm{S}$ were positive. The economic analysis reveals that most of the treatments produced BCR (benefitcost ratio) of more than 3.0 showing that they all are economically viable. The integrated use of fertilizers and manure resulted in considerable improvement in soil health by increasing organic matter, available $\mathrm{P}$, and $\mathrm{S}$ contents of soils. The overall findings of the study indicate that the integrated use of chemical fertilizer and manure is important for sustainable crop yield in a rice-rice cropping pattern.
\end{abstract}

Kew Words: Organic manures, chemical fertilizer, soil health.

${ }^{1}$ Scientific Officer, Soil Science Division, BARI, Joydebpur, Gazipur, ${ }^{2 \& 3}$ Professor, Deptt. of Soil Science, BAU, Mymensingh, Bangladesh. 


\section{Introduction}

Soil fertility deterioration is a major constraint for higher crop production in Bangladesh. The increasing land use intensity without adequate and balanced use of chemical fertilizers and with little or no use of organic manure have caused severe fertility deterioration of our soils resulting in stagnating or even declining of crop productivity. The farmers of this country use, on an average, $172 \mathrm{~kg}$

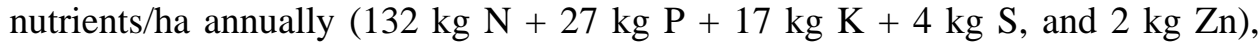
while the crop removal is about $250 \mathrm{~kg} / \mathrm{ha}$ (Islam, 2002). Since fertile soil is the fundamental resource for higher crop production, its maintenance is a prerequisite for long- term sustainable crop productivity. Soil organic matter is a key factor for sustainable soil fertility and crop productivity. Organic matter undergoes mineralization with the release of substantial quantities of N, P, and S. and smaller amount of micronutrients. In Bangladesh, most of the cultivated soils have less than $1.5 \%$ organic matter, while a good agricultural soil should contain at least $2 \%$ organic matter. Moreover, this important component of soils is declining with time due to intensive cropping and use of higher doses of nitrogenous fertilizers with little or no addition of organic manure. Consequently, $\mathrm{Zn}$ and B deficiencies are frequently reported on some soils and crops (Jahiruddin et al., 1995 and Mondal el al., 1992). Rice (Oryza sativa L.) is intensively cultivated in Bangladesh covering about $80 \%$ of arable land. Unfortunately, the yield of rice in this country is low (3.4 t/ha) compared to other rice growing countries like South Korea and Japan where the average yield is 6.00 and $5.6 \mathrm{t} / \mathrm{ha}$, respectively (FAO, 2003). On the other hand, the demand for increasing rice production is mounting up to feed the ever-increasing population.

A suitable combination of organic and inorganic source of nutrients is necessary for sustainable agriculture that can ensure food production with high quality (Reganold et al., 1990). Nambiar (1991) viewed that integrated use of organic manure and chemical fertilizers would be quite promising not only in providing greater stability in production, but also in maintaining better soil fertility. The long-term research of BRRI revealed that the application of cowdung $5 \mathrm{t} / \mathrm{ha} / \mathrm{yr}$ improved rice productivity as well as prevented the soil resources from degradation (Bhuiyan, 1994). Thus, it is necessary to use fertilizer and manure in an integrated way in order to obtain sustainable crop yield without affecting soil fertility. Based on the soil fertility problem as discussed above, the present study was undertaken to investigate the effect of combined use of chemical fertilizers and organic manures in a rice-rice cropping system.

\section{Materials and Method}

A field experiment was conducted during 2003-2004 at Bangladesh Agricultural University farm, Mymensingh to evaluate the suitability of different sources of organic materials for integrated use with chemical fertilizers for the BoroFalIow-T. Aman rice cropping pattern. The soil was non-Calcareous Dark Grey 
Floodplain. The cultivars used were BRRI dhan-29 and BRRI dhan-31 for Boro and T.Aman rice, respectively. The experiment was designed with eight treatments for both the crops. The experiment was laid out in a randomized complete block design with three replications. The unit plot size was $5 \mathrm{~m} \times 4 \mathrm{~m}$. The treatment combinations were: $\mathrm{T}_{1}$ (control), $\mathrm{T}_{2}$ (70\% NPKS), $\mathrm{T}_{3}(100 \%$ NPKS), $\mathrm{T}_{4}(70 \% \mathrm{NPKS}+\mathrm{RS}), \mathrm{T}_{5}(70 \% \mathrm{NPKS}+\mathrm{DH}), \mathrm{T}_{6}(70 \% \mathrm{NPKS}+\mathrm{MBR})$, $\mathrm{T}_{7}(70 \%$ NPKS $+\mathrm{CD})$ and $\mathrm{T}_{8}(70 \% \mathrm{NPKS}+\mathrm{PM})$. The rates of chemical fertilizers were fixed on soil test basis (STB) with a high yield goal (HYG) target as per Fertilizer Recommendation Guide (BARC, 1997).Thirty-five days old seedlings were used for transplanting in both Boro and T. Aman seasons. T. Aman was transplanted on 5 August and harvested on 29 November 2003. For Boro, the crop was transplanted on 28 January and harvested on 29 May 2004. The initial soil status and the composition of different organic manures are given in Table 1 and 2.

Table 1. General characteristics of initial soil.

\begin{tabular}{ll}
\hline Characteristics & Value \\
\hline \% Sand & 17.4 \\
\% Silt & 67.0 \\
\%Clay & 15.6 \\
Textural class & Silt loam \\
$\mathrm{pH}$ (Soil: Water = 1:2.5) & 6.8 \\
Organic carbon (\%) & 1.15 \\
Organic matter (\%) & 1.99 \\
CEC (me/I00 g soil) & 10.10 \\
Total N (\%) & 0.077 \\
C:N ratio & 9.30 \\
Available P (ppm) & 12.0 \\
Available S (ppm) & 13.9 \\
Available Zn (ppm) & 1.62 \\
Exchangeable K (me/I00 g soil) & 0.13 \\
\hline
\end{tabular}

Table 2. Chemical composition of different organic manures.

\begin{tabular}{l|l|c|c|c|c|c}
\hline \multirow{2}{*}{ Organic materials } & \multicolumn{7}{c}{ Nutrient composition (\%) } \\
\cline { 2 - 8 } & $\mathrm{H}_{2} \mathrm{O}$ & $\begin{array}{c}\text { Organic } \\
\text { carbon }\end{array}$ & $\mathrm{N}$ & $\mathrm{P}$ & $\mathrm{K}$ & $\mathrm{S}$ \\
\hline Rice straw & 22 & 15.4 & 0.55 & 0.18 & 1.47 & 0.13 \\
Dhaincha & 80 & 18.5 & 1.55 & 0.37 & 1.47 & 0.12 \\
Mungbean residues & 70 & 16.8 & 1.12 & 0.27 & 1.05 & 0.12 \\
Cowdung & 40 & 10.5 & 1.13 & 0.27 & 0.68 & 0.15 \\
Poultrymanure & 20 & 12.6 & 2.70 & 0.52 & 1.58 & 0.15 \\
\hline
\end{tabular}


The rates of $\mathrm{N}, \mathrm{P}, \mathrm{K}$, and $\mathrm{S}$ for the first crop (T. Aman rice) and second crop (Boro rice) were 100, 15, 45, and $10 \mathrm{~kg} / \mathrm{ha}$, and 140, 25, 60, and $20 \mathrm{~kg} / \mathrm{ha}$ respectively. Five different sources of organic matters, viz., rice straw (RS), dhaincha (DH), mungbean residues (MBR), cowdung (CD), and poultry manure (PM) were applied @ 5, 15, 10, 5, and 3 t/ha, respectively, during T. Aman season only. Mungbean was grown during April to July and Dhaincha during May to July in the field adjacent to the experimental plots. Sixty and sixty-five days old decomposed dhaincha and mungbean residue were applied 4 days before transplanting of T. Aman rice. Urea was applied in three equal splits. The first split was applied during final land preparation, the second split at active tillering stage and the remaining split at panicle initiation stage of the crop. Organic manure was applied to soil before final land preparation. All the cultural practices like weeding, irrigation, insecticide spray, etc. were done in time. Grain and straw were analyzed separately for determination of N, P, K, and S contents. All the data were analyzed statistically following the F-test and the mean comparisons were made by DMRT at $5 \%$ level.

\section{Results and Discussion}

\section{Grain and straw yield of the crops}

Grain and straw yields of T. Aman rice (var. BRRI dhan-3l) responded significantly to the different treatment combinations (Table 3). The highest grain yield (5.52 t/ha was obtained in $\mathrm{T}_{8}(70 \% \mathrm{NPKS}+\mathrm{PM})$ treatment, which was significantly higher than $\mathrm{T}_{1}$ (control), $\mathrm{T}_{2}(70 \% \mathrm{NPKS})$ and $\mathrm{T}_{4}(70 \% \mathrm{NPKS}+\mathrm{RS}$ ) treatments, but statisticaly identical with $\mathrm{T}_{3}(100 \% \mathrm{NPKS}), \mathrm{T}_{5}$ (70\% NPKS + $\mathrm{DH}), \mathrm{T}_{6}(70 \% \mathrm{NPKS}+\mathrm{MBR})$ and $\mathrm{T}_{7}(70 \% \mathrm{NPKS}+\mathrm{CD})$ treatments. Treatment $\mathrm{T}_{8}(70 \% \mathrm{NPKS}+\mathrm{PM})$ resulted in $94 \%$ grain yield increase over the control. The lowest grain yield (2.84 t/ha was observed in $\mathrm{T}_{1}$ (control) treatment. The second highest grain yield (5.42 $\mathrm{t} / \mathrm{ha}$ ) was recorded in $\mathrm{T}_{3}(100 \%$ NPKS) treatment. The straw yield of T. Aman rice varied from 4.05 to $6.73 \mathrm{t} / \mathrm{ha}$. The highest straw yield (6.73 t/ha) was observed in $\mathrm{T}_{8}(70 \%$ NPKS + PM) treatment, which was statistically higher than all other treatments. The lowest straw yield (4.05 t/ha) was obtained in $\mathrm{T}_{1}$ (control) treatment. These results agree to that of the earlier workers (Saleque et al., 2004; Haque, 1998 and Ishaque, 1998). Thus, the results indicate that nutrients for high yield goal based on soil analysis without organic manures increased the grain yield and decreased the straw yield. But the nutrients with organic manures increased both straw and grain yields.

Grain and straw yields of Boro rice (var. BRRI dhan-29) were also significantly influenced by the different combinations. Generally, each and every treatment produced significantly higher grain yield over control. Both grain and straw yields of Boro rice varied from 2.30 to $6.87 \mathrm{t} / \mathrm{ha}$ and 2.43 to $6.92 \mathrm{t} / \mathrm{ha}$, respectively (Table 3 ). The highest grain yield was found in $T_{3}$ treatment, and 
gave 199\% higher yield over the control, but that was statistically identical with $\mathrm{T}_{8}$ (6.57 t/ha) treatment. These result was similar to the earlier findings of some workers (Rajni et al., 2001; Rahman, 2001; Channabasavanna and Birandar, 2001). On the other hand, the highest straw yield was obtained in $T_{3}$ and gave $185 \%$ higher yield over control. The lowest straw yield was observed in $T_{1}$ (control) treatment. Above results were also observed by different workers (Ishaque, 1998; Purushotham and Sadashiviab, 1993; Hossain et al., 1997 and Sajjad, 1995). All the organic manures had residual effects on Boro rice. The residual effects of manures may be ranked in order of $\mathrm{PM}>\mathrm{DH}>\mathrm{MBR}>\mathrm{CD}>$ RS. Thus, it may be concluded that the treatment of $T_{3}(100 \%$ NPKS) showed the best performance in respect of grain and straw yields of Boro rice. But treatment $\mathrm{T}_{8}$ (70\% NPKS plus residual PM) also showed statistically similar performances.

Table 3. Effects of different treatment on grain and straw yields of cropping pattern and nutrient uptake by the crops.

\begin{tabular}{|c|c|c|c|c|c|c|c|c|}
\hline \multirow[t]{3}{*}{ Treatments } & \multicolumn{4}{|c|}{ Yield (t/ha) } & \multicolumn{4}{|c|}{$\begin{array}{c}\text { Nutrient uptake (kg/ha) } \\
\begin{array}{c}\text { (T.Aman + Boro and Grain } \\
+ \text { Straw) }\end{array}\end{array}$} \\
\hline & \multicolumn{2}{|c|}{ T.Aman } & \multicolumn{2}{|c|}{ Boro } & \multirow[t]{2}{*}{$\mathrm{N}$} & \multirow[t]{2}{*}{$\mathrm{P}$} & \multirow[t]{2}{*}{ K } & \multirow[t]{2}{*}{$\mathrm{S}$} \\
\hline & Grain & Straw & Grain & Straw & & & & \\
\hline $\mathrm{T}_{1}$ : Control & $2.84 \mathrm{c}$ & $4.05 \mathrm{~g}$ & $2.30 \mathrm{~d}$ & 2.43e & 69 & 12 & 91 & 6 \\
\hline $\mathrm{T}_{2}: 70 \% \mathrm{NPKS}$ & $4.65 b$ & $5.56 f$ & $6.06 c$ & $6.18 \mathrm{~d}$ & 160 & 32 & 222 & 16 \\
\hline $\mathrm{T}_{3}: 100 \% \mathrm{NPKS} *$ & $5.42 \mathrm{a}$ & $6.28 \mathrm{~d}$ & $6.87 a$ & $6.92 a$ & 212 & 41 & 248 & 21 \\
\hline $\mathrm{T}_{4}: 70 \% \mathrm{NPKS}+\mathrm{RS}$ & $4.78 \mathrm{~h}$ & $6.12 \mathrm{~cd}$ & $6.08 c$ & $6.30 \mathrm{~d}$ & 168 & 30 & 210 & 16 \\
\hline $\mathrm{T}_{5}: 70 \% \mathrm{NPKS}+\mathrm{DH}$ & $5.10 \mathrm{ab}$ & $6.50 \mathrm{~b}$ & $6.27 \mathrm{bc}$ & 6.37cd & 192 & 34 & 237 & 18 \\
\hline $\mathrm{T}_{6}: 70 \% \mathrm{NPKS}+\mathrm{MBR}$ & $5.27 a b$ & $6.39 c$ & $6.32 b c$ & $6.55 b c$ & 194 & 38 & 237 & 20 \\
\hline $\mathrm{T}_{7}: 70 \% \mathrm{NPKS}+\mathrm{CD}$ & 4.9lab & $6.15 \mathrm{e}$ & 6.13bc & $6.41 \mathrm{~cd}$ & 185 & 34 & 233 & 18 \\
\hline $\mathrm{T}_{8}: 70 \% \mathrm{NPKS}+\mathrm{PM}$ & $5.52 \mathrm{a}$ & $6.73 a$ & $6.57 \mathrm{ab}$ & 6.69ab & 210 & 42 & 260 & 21 \\
\hline CV (\%) & 3.78 & 0.66 & 3.16 & 1.57 & - & - & - & - \\
\hline$S x$ & 0.11 & 0.02 & 0.33 & 0.06 & - & - & - & - \\
\hline
\end{tabular}

T.Aman $=\mathrm{N}_{100} \mathrm{P}_{15} \mathrm{~K}_{45} \mathrm{~S}_{10} \mathrm{~kg} / \mathrm{ha}$

Boro $=\mathrm{N}_{140} \mathrm{P}_{25} \mathrm{~K}_{60} \mathrm{~S}_{20} \mathrm{~kg} / \mathrm{ha}$

\section{Nutrient uptake}

The result (Table 3) revealed wide variation in nutrient uptake pattern of different treatments. The highest $\mathrm{N}$ uptake was recorded in $\mathrm{T}_{3}$ treatment and the lowest in $\mathrm{T}_{1}$ (control). The second highest was in treatment $\mathrm{T}_{8}$. The present observation was similar with earlier findings (Ishaque, 1998). The $\mathrm{P}$ uptake varied from 12 to $42 \mathrm{~kg} / \mathrm{ha}$. The highest $\mathrm{P}$ uptake recorded in $\mathrm{T}_{8}$ and the lowest was in $\mathrm{T}_{1}$ (control). The total $\mathrm{K}$ uptake ranged from 91 to $260 \mathrm{~kg} / \mathrm{ha}$. The highest $\mathrm{K}$ uptake in $\mathrm{T}_{8}$ and the lowest in $T_{1}$ (control). The total uptake of $S$ ranged from 6 to $21 \mathrm{~kg} / \mathrm{ha}$. Like all nutrients, the highest total $\mathrm{S}$ uptake was also observed in $\mathrm{T}_{8}$ and lowest in $\mathrm{T}_{1}$ (control). Total nutrient uptake by T. Aman and Boro rice showed wide variation 
in different treatments (Table 3). The total uptake of nutrients (NPKS) ranged from I $78 \mathrm{~kg} / \mathrm{ha} / \mathrm{yr}$ in $\mathrm{T}_{1}$ (control) treatment to $533 \mathrm{~kg} / \mathrm{ha} / \mathrm{yr}$ in $\mathrm{T}_{8}(70 \%$ NPKS + $\mathrm{PM})$. Total uptake in the treatment $\mathrm{T}_{2}\left(70 \%\right.$ NPKS) was $430 \mathrm{~kg} / \mathrm{ha} / \mathrm{yr}$, while in $\mathrm{T}_{3}$ (100\% NPKS) was $522 \mathrm{~kg} / \mathrm{ha} / \mathrm{yr}$ The application of DH, MBR, CD or PM with $70 \%$ NPKS resulted in considerable higher uptake of nutrients by the crops compared to 70\% NPKS application.

\section{Changes in soil health}

Application of organic manure and crop residue with chemical fertilizer increased the organic matter, total $\mathrm{N}$, available $\mathrm{P}$, available $\mathrm{S}$ and exchangeable $\mathrm{K}$ contents of soil (Table 4). There were little changes in soil $\mathrm{pH}$ due to chemical fertilizers alone or with any source of organic manure. The organic matter status was considerably improved due to the application of organic manure or crop residue. The organic matter varied from 1.75 to 2.22 over the treatments. The increase in total $\mathrm{N}$ might be due to the direct addition of $\mathrm{N}$ through organic manure added to the soil. Increase in exchangeable $\mathrm{K}$ due to the application of organic manure might be attributed to the release of $\mathrm{K}$ to the available pool of the soil besides the reduction of $\mathrm{K}$ fixation. These results are similar with the findings of some earlier workers (Saleque et al., 1991; Bhardwaj and Omanwar, 1994). The available $P$ and $S$ also increased due to use of organic manures.

Table 4. Effects of different chemical fertilizers and organic manures on soil properties.

\begin{tabular}{l|c|c|c|c|c|c|c}
\hline \multicolumn{1}{c|}{ Treatments } & $\mathrm{pH}$ & $\mathrm{OM}$ & $\begin{array}{c}\text { Total N } \\
(\%)\end{array}$ & $\begin{array}{c}\text { Available } \\
\mathrm{P}(\mathrm{ppm})\end{array}$ & $\begin{array}{c}\text { Exchange } \\
\text {-able }\end{array}$ & $\begin{array}{c}\text { Available } \\
\mathrm{S}\end{array}$ & $\begin{array}{c}\text { Available } \\
\text { Zn }\end{array}$ \\
\hline Initial soil & 6.8 & 1.99 & 0.077 & 12.0 & 0.13 & 13.9 & 1.62 \\
Postharvest soil & & & & & & & \\
$\mathrm{T}_{1}:$ Control & 6.95 & 1.80 & 0.068 & 10.84 & 0.101 & 1.4 & 1.37 \\
$\mathrm{~T}_{2}: 70 \% \mathrm{NPKS}$ & 6.79 & 1.75 & 0.074 & 15.52 & 0.14 & 14.3 & 1.27 \\
$\mathrm{~T}_{3}: 100 \%$ NPKS & 6.92 & 1.78 & 0.078 & 17.04 & 0.16 & 17.6 & 1.08 \\
$\mathrm{~T}_{4}: 70 \% \mathrm{NPKS}+\mathrm{RS}$ & 7.02 & 1.90 & 0.082 & 13.28 & 0.14 & 15.6 & 1.15 \\
$\mathrm{~T}_{5}: 70 \% \mathrm{NPKS}+\mathrm{DH}$ & 6.78 & 2.15 & 0.086 & 20.34 & 0.15 & 17.0 & 1.20 \\
$\mathrm{~T}_{6}: 7 \mathrm{ONPKS}+\mathrm{MBR}$ & 7.02 & 2.05 & 0.080 & 20.30 & 0.15 & 17.1 & 1.32 \\
$\mathrm{~T}_{7}: 70 \%$ NPKS +CD & 6.83 & 2.16 & 0.087 & 18.00 & 0.14 & 13.5 & 1.34 \\
$\mathrm{~T}_{8}: 70 \% \mathrm{NPKS}+\mathrm{PM}$ & 6.72 & 2.22 & 0.089 & 21.30 & 0.16 & 20.8 & 1.37 \\
\hline
\end{tabular}

\section{Soil nutrient balance}

In the present study, an attempt was also made to find out the apparent nutrient balance as affected by different organic and inorganic fertilizer management packages in Boro-Fallow-T. Aman cropping pattern. In calculating apparent 
nutrient balance in the pattern, it is assumed that $40 \%$ of the applied $\mathrm{N}$ from urea was considered effective. In case of organic manure or plant residues, $50 \%$ of the $\mathrm{N}$ was considered available for plants. The concentration of $\mathrm{K}$ in the irrigation water was $3.0 \mathrm{ppm}$. Assuming that a Boro rice crop requires $100 \mathrm{~cm}$ water, the amount of $\mathrm{K}$ added through irrigation water was $30 \mathrm{~kg} / \mathrm{ha}$. Results demonstrated that the $\mathrm{N}$ balance was highly negative (Fig. 1). The $\mathrm{P}$ and $\mathrm{S}$ balances were slightly positive (Fig. 2 \& 3). It was reflected that a large amounts of $\mathrm{P}$ and $\mathrm{S}$ accumulated in the fertilized plots. But in case of $\mathrm{K}$, it was evident from the data that $\mathrm{K}$ uptake by the crops far exceeded than that was replenished from fertilization (Fig. 4). This will lead the K depletion in the long run. Application of cowdung, poultry manure improved the overall nutrient balance in soil. These results are in agreement with the findings of Haque et al. (2001) \& Ishaque (1998).

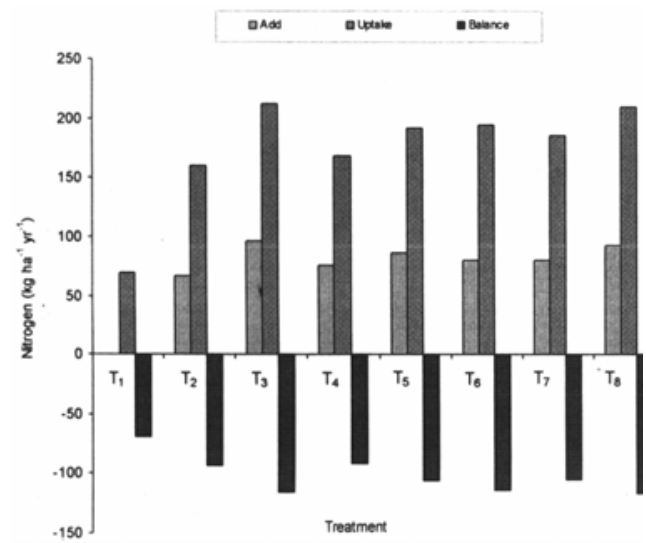

Fig. 1. Apparent $\mathrm{N}$ balance in soils as a affected by different treatments.

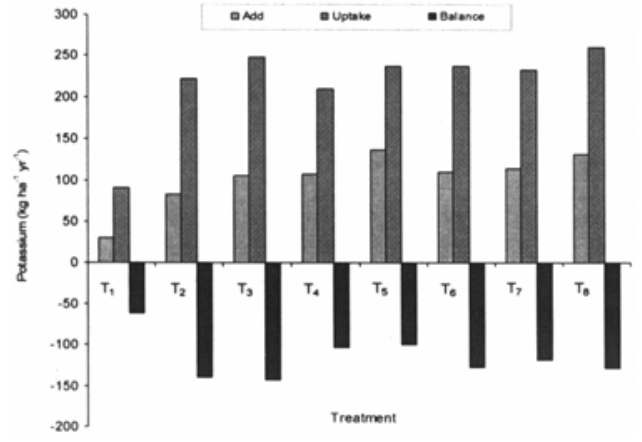

Fig. 3. Apparent $\mathrm{K}$ balance in soils as a affected by different treatments.

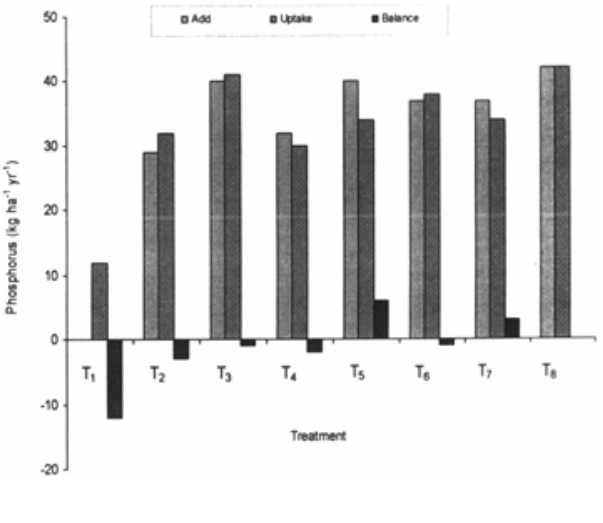

Fig. 2. Apparent $\mathrm{P}$ balance in soils as a affected by different treatments.

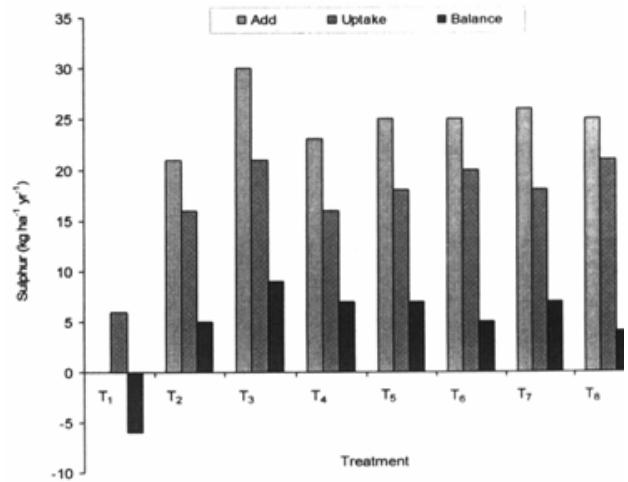

Fig. 4. Apparent $\mathrm{S}$ balance in soils as a affected by different treatments. 


\section{Economic analysis}

Economic yields and added benefits as influenced by integrated use of chemical fertilizers and organic materials on rice have been calculated and presented in Table 5. The highest grain and straw yields of $12.29 \mathrm{t} / \mathrm{ha}$, recorded in $\mathrm{T}_{3}(100 \%$ NPKS) gave the highest gross return of Tk. 1,11,520 (Table 4). The second highest gross return of Tk. 1,10,140 was found in $\mathrm{T}_{8}(70 \% \mathrm{NPKS}+\mathrm{PM})$. The results showed that all the treatments have $\mathrm{B}$ : $\mathrm{C}$ ratios higher than 3.0 (Table 5). The highest B: C ratio of 5.24 was found in $\mathrm{T}_{2}$ (70\% NPKS) followed by 5.14 in $\mathrm{T}_{8}(70 \% \mathrm{NPKS}+\mathrm{PM})$.

Table 5. Economic analysis as influenced by integrated use of chemical fertilizers and organic materials on rice-rice (Boro-Fallow-T.Aman) cropping pattern.

\begin{tabular}{|c|c|c|c|c|c|c|}
\hline \multirow[t]{2}{*}{ Treatments } & \multicolumn{2}{|c|}{ Economic yields (t/ha) } & \multirow{2}{*}{$\begin{array}{c}\text { Gross } \\
\text { return } \\
\text { (Tk./ha/yr) }\end{array}$} & \multirow{2}{*}{$\begin{array}{c}\text { Net return } \\
(\mathrm{Tk} . / \mathrm{ha} / \mathrm{yr})\end{array}$} & \multirow{2}{*}{$\begin{array}{c}\text { TVC } \\
\text { (Tk./ha) }\end{array}$} & \multirow[t]{2}{*}{ BCR } \\
\hline & Grain & Straw & & & & \\
\hline $\mathrm{T}_{1}$ : Control & 5.14 & 6.48 & 47600 & - & - & - \\
\hline $\mathrm{T}_{2}: 70 \% \mathrm{NPKS}$ & 10.71 & 11.74 & 97420 & 49820 & 9513 & 5.24 \\
\hline $\mathrm{F}_{3}: 100 \% \mathrm{NIKS}$ & 12.29 & 13.20 & 111520 & 63920 & 13120 & 4.87 \\
\hline $\mathrm{T}_{4}: 70 \% \mathrm{NPKS}+\mathrm{RS}$ & 10.86 & 12.42 & 99300 & 51700 & 14513 & 3.56 \\
\hline $\mathrm{T}_{5}: 70 \% \mathrm{NPKS}+\mathrm{DH}$ & 11.37 & 12.87 & 103360 & 55760 & 14943 & 3.73 \\
\hline $\mathrm{T}_{6}: 70 \% \mathrm{NPKS}+\mathrm{MBR}$ & 11.59 & 12.94 & 105660 & 58060 & 15963 & 3.64 \\
\hline $\mathrm{T}_{7}: 70 \% \mathrm{NPKS}+\mathrm{CD}$ & 11.04 & 12.56 & 100880 & 53280 & 12033 & 4.43 \\
\hline $\mathrm{T}_{8}: 70 \% \mathrm{NPKS}+\mathrm{PM}$ & 12.09 & 13.42 & 110140 & 62540 & 12203 & 5.14 \\
\hline
\end{tabular}

\section{Conclusion}

Bangladesh is a rice based country. Only chemical fertilizer is not judicious for producing any crop. Integrated use of chemical fertilizers and organic manure is necessary for crop production as well as maintaining soil fertility. The findings of the experiment revealed that $70 \%$ of recommended dose of chemical fertilizers and 3 tons poultry manure per hectare performed better production. Therefore, 30 percent of chemical fertilizer may be replenished by organic manure which is economically viable for the farmers.

\section{References}

Bharadwaj, V. and P.K. Omanwar. 1994. Long-term effects of continuous rotational cropping and fertilizer on crop yield and soil properties II. Effects on EC, pH, organic matter and available nutrients of rice. J. Indian Soc. Soil Sci. 42: 387.

Bhuiyan, N.I. 1994. Crop production trends and need of sustainability in agriculture. Paper presented at the workshop Integrated Nutrient Management for Sustainable Agriculture, held at SRDI, Dhaka. Bangladesh during June 26-28, 1994. 
Channabasavanna, A.S. and D.P. Birandar. 2001. Response of irrigated rice to the application of poultry manure and inorganic fertilizer N, P, and K in Karnata, India. Int. Rice Res. Newslett. 26(2): 64-65.

FAO. 2003. Yearbook of Production. Food and Agricultural Organization. FAO, Statistics Division. pp. 57: 76-77.

BARC. 1997. Fertilizer Recommendation Guide. Pub. No. 41. Bangladesh Agricultural Research Council, Farmgate. Dhaka.

Haque, M.S. 1998. Proceedings of the national workshop on integrated nutrient management for crop production and soil production and soil fertility. On Farm Research Division, Bangladesh Agricultural Research Institute, Joydebpur, Gazipur1701.

Haque, M.Q., M.H. Rahman, F. Islam, J. Rijpma and M.M. Kadir. 2001. Integrated nutrient management in relation to soil fertility and yield sustainability under WheatMung-T.Aman cropping pattern. Online J. Biol. Sci. 1(8): 73 1-734.

Hossain, M.B., M.R. Islam, M.M. Rahman, and M. Jahiruddin. 1997. Effect of integrated nutrient management on yield and yield components of BR II rice. Progress. Agric. 8(1\&2): 83-86.

Ishaque, M. 1998. Integrated nutrient management with inorganic fertilizers organic manures for Boro-T.aman rice cropping pattern. Soil Science Division, Bangladesh Agricultural Research, Gazipur. p 113.

Islam, M.S. 2002. Soil Fertility History, Present Status and Future Scenario in Bangladesh. Paper presented at the Training Course on Soil Fertility and Fertilizer Management held at CERDI, Gazipur, 9 Sept. 2002.

Jahiruddin, M., M.S. Ali, M.A. Hossain, M.U. Ahrned, and M.M. Hoque. 1995. Effect on boron on grain set, yield and some other parameters of wheat cultivars. Bangladesh J. Agric. Sci. 22: 179.

Mondal, M.H.R., M. Jahiruddin, M.M. Rahman, and M.A. Hashem. 1992. An investigation on nutrient requirement of BR-Il rice Old Brahmaputra Floodplain Soil. Bangladesh J. Crop Sci. 2(2): 22-3 1.

Nambiar, K.K.M. 1991. Long-term fertility effects on wheat productivity. Wheat for the non traditional warm areas. Proceedings International Conference, Mexico, DF (Mexico) CIMMYT, 1991, 5 16-521.

Purushotham, S. and T. Sadashiviab. 1993. Response of paddy to NPK and Zn in the cultivated fields of Kalar district. Mysorey of Agril. Sci. 27(2): 112-117 [Field Crop Abst. 49(5): 3951.

Rahman, M.A. 2001. Integrated use of fertilizer and manure for crop production in wheat-rice and rice-rice cropping patterns. Ph.D. Thesis. Dept. Soil Sci., Bangladesh AgriI. Univ., Mymensingh.

Rajni, R., O.P. Srivastava, and R. Rani. 2001. Effect of integration of organics with fertilizer $\mathrm{N}$ on rice and $\mathrm{N}$ uptake. Fert. News. 46(9): 63-65.

Reganold, J.P., I.P. Robert, and J.F. Parr. 1990. Sustainability of agriculture in the United States-An overview. Proc. Sustainable Agriculture, Issues, Prospectives and Prospects in Semi Arid Tropics. Singh, R.P. (ed.). 
Sajjad, M.S. 1995. Influence of different N, P, K doses on yield and yield components of two standard rice varieties of PNG, under lowland field conditions. Papua New Guinea J. Agric. Forestry and Fisheries 38(2): 124-126.

Saleque, M.A., M.S. Abedin, N.I. Bhuiyan, S.K. Zaman, and G.M. Panaullah. 2004. Longterm effect of inorganic and organic fertilizer sources on yield and nutrient accumulation of lowland rice. Field Crops Res. 86: 53-65.

Saleque, M.A., G.M. Panaullah, S. K. Zaman, and N.I. Bhuiyan. 1991. Residual effect ol chemical fertilizer and rice straw on soil properties and yield of wetland rice. Bangladesh J. Soil. Sci. 22(1\&2): 17-24. 